\title{
Pementasan Teater Lingkungan "Sirna Ilang Kertaning Bumi” Refleksi Konflik Horizontal di Indonesia
}

\author{
Wahid Nurcahyono ${ }^{1}$ \\ Jurusan Teater, Fakultas Seni Pertunjukan, Institut Seni Indonesia Yogyakarta.
}

\begin{abstract}
ABSTRAK
Bentuk teater lingkungan merupakan sebuah karya seni yang bukan saja menghibur tetapi juga memberikan tawaran-tawaran bentuk penyajian lain dari yang lazim dipergunakan. Bentuk semacam ini diharapkan mampu mendekatkan permainan kepada penonton secara langsung karena penonton tidak perlu lagi mendatangi tempat pertunjukan akan tetapi permainanlah yang akan menjemput mereka di ruang-ruang publik di luar panggung. Aksi dan interaksi secara langsung antara penonton dan permainan mengajak peran serta aktif penonton untuk merasakan langsung teks-teks yang disampaikan pemain. Meskipun bentuk-bentuk kesenian yang melibatkan penonton secara aktif telah dimiliki oleh masyarakat, misalnya upacara adat dan seremoni yang lain, akan tetapi hal tersebut jarang dilakukan pembaharuan dan hanya bersifat warisan atau tradisi saja. Maka dalam proses ini sutradara mencoba menghadirkan bentuk teater lingkungan dalam sebuah ruang 'Rumah Makan' yang mengambil cerita rakyat masa lalu yang diolah dan disesuaikan dengan masyarakat saat ini. Kemampuan sutradara untuk mengarahkan serta memberi ruang dalam berkreasi bagi pemainnya sangatlah penting. Sementara itu pemain yang memiliki kecakapan di bidangnya harus siap melakukan improvisasi untuk menghadapi aksi dan interaksi secara spontan dengan penonton.
\end{abstract}

Kata kunci: teater lingkungan, ruang publik, sirna ilang, interteks.

\begin{abstract}
Performing Environment Theatre "Sirna Ilang Kertaning Bumi". A Reflection on the Horizontal Conflict in Indonesia. The form of environmental theater is a work of art which is not only entertaining but also providing a way of presenting different forms than that commonly used. This form is expected to bring the theatre to a live audience because the audience does not need to go to the venue but the theatre will meet them in public spaces outside stage. Action and direct interaction between the audience and the theatre invite active participation of the audience to feel directly the texts presented by the actors. Although the art forms involving the audience actively have been owned by the community, such as custom ceremonies and other ceremonies, those are rarely renewed, and they remain as customs and tradition. Therefore, in this process the director tried to present the form of environment theater in a space of "Restaurant" presenting a folklore which had been processed and adapted to today's society. The ability of the director in directing and providing room for the players to be creative was very important. While players who have skill in their art, they must be ready to confront improvised acts and spontaneous interaction with the audience.
\end{abstract}

Key words: environmental theater, public space, sirna ilang, intertex.

\section{Pendahuluan}

Peristiwa konflik horizontal dengan latar belakang perbedaan keyakinan, sosial, dan ekonomi akhir-akhir ini marak terjadi. Hal ini bersamaan dengan semakin terbukanya peluang berbagai kalangan untuk menyampaikan pendapat secara lebih leluasa. Konflik tersebut diiringi dengan menurunnya kualitas hidup dan perekonomian sebagian besar masyarakat. Akan tetapi juga menimbulkan opini bahwa konflik berlandaskan perbedaan tersebut hanyalah pelarian saja untuk mengalihkan perhatian masyarakat terhadap ketidakpuasan kinerja penyelenggara negara.
Dengan runtuhnya rezim Orde Baru pada 1998, muncul apa yang disebut era reformasi, yang sudah berjalan lima tahun sampai sekarang. Di era inilah berbagai konflik berdarah kembali menyeruak secara vertikal dan horizontal, seakan mengulangi apa yang terjadi pada 1950-an dan awal 1960-an. Konflik vertikal adalah kelanjutan konflik di Aceh dan juga Papua. Konflik horizontal terjadi di Sampit, Kalimantan Tengah, karena kesenjangan sosio-ekonomi dan tidak lancarnya komunikasi antar-etnis. Konflik Maluku, seperti kasus Sampit, lebih dipicu oleh masalah kesenjangan dan kepentingan politik, sedangkan

1 Alamat korespondensi: Jurusan Teater, Fakultas Seni Pertunjukan. ISI Yogyakarta. Jalan Parangtritis Km 6,5 Sewon, Yogyakarta 55001. Telepon (0274) 384 108. E-mail: wahid@isi.ac.id 
kasus Poso pada awalnya bersifat politik. Berkat perjanjian Malino I dan II, situasi Poso dan Maluku sudah berangsur pulih. Apa yang tersisa adalah masalah rehabilitasi kerusakan akibat konflik. Apakah konflik-konflik horizontal di era reformasi ini karena agama atau karena hal lain? Berbagai penelitian menyatakan bahwa semua konflik itu pada mulanya bukan karena perbedaan agama, tetapi lebih disebabkan oleh rasa keadilan yang tertindas.

Dari fakta tersebut terlihat bahwa masyarakat mulai kritis dalam beropini. Masyarakat tidak lagi takut untuk menyampaikan aspirasinya secara langsung. Bentuk-bentuk pengungkapan aspirasi secara langsung terlihat dengan maraknya aksi demonstrasi di jalan raya atau tempat-tempat umum lainnya. Hal ini memberikan inspirasi bagi penciptaan sebuah karya seni teater, sehingga melalui penciptaan seni teater ini penulis ingin menyampaikan salah satu dampak konflik horizontal tersebut. Betapa kengerian yang ditimbulkan olch konflik tersebut dekat dengan kehidupan kita saat ini. Salah satu pihak yang diharapkan ikut berperan dalam menurunkan tingkat konflik tersebut salah satunya adalah pers. Pers merupakan jendela informasi bagi masyarakat yang sangat berpengaruh di mana era demokrasi mulai beranjak ke arah pendewasaan.

Sekarang pers bisa juga mempunyai andil dalam suatu kejahatan tetapi kejahatan tersebut dinilai sebagai kebenaran yang didukung oleh berbagai kalangan, sehingga situasi ini sangat membingungkan bagi masyarakat awam. Poskriminalitas adalah sebuah kondisi ketika kejahatan tampil dalam bentuk simulasinya, yaitu simulasi kejahatan (simulation of crime). Simulasi kejahatan adalah kejahatan yang dengan sengaja diciptakan atau direkayasa oleh pihak tertentu lewat teknologi pencitraan (imagologi) dan teknik narasi (narrative). Kejahatan tersebut direpresentasikan lewat media tertentu, sehingga realitas kejahatan dan kebenaran (truth) ada di baliknya, seakanakan seperti yang tampil di dalam media tersebut. Padahal, representasi tersebut adalah hasil dari manipulasi media semata. Namun jika pemberitaan pers bisa berimbang dan faktual maka diharapkan akan bisa meredam konflik yang sangat potensial di Indonesia. Pers harus mempunyai peranan yang besar dalam ikut membentuk kepribadian masyarakat di Indonesia sehingga tercipta masyarakat yang berkehidupan harmonis dan penuh perdamaian (Piliang, 2004: 165).

Jika kita mau menilik kisah masa lampau, peristiwa konflik horizontal tersebut mempunyai kemiripan dengan peristiwa kemunculan Demak (sebuah kerajaan berideologi Islam) yang dijadikan kambing hitam sebagai penyebab runtuhnya Majapahit. Untuk menutup kemunduran yang ditimbulkannya, pujangga keraton menyatakan bahwa kehadiran Demak merupakan Sirna Ilang Kertaning Bumi (1400), 'Lenyap Hilang Kemakmuran Dunia (Jawa)' sebagai candrasengkala jatuhnya Majapahit oleh Demak. Candrasengkala adalah pemindahan kekuasaan Majapahit ke Demak yang ternyata tidak menjadikan kerajaan menjadi lebih baik daripada sebelumnya. Penghadiran Candrasengkala itu lebih dapat dikatakan merupakan hasil terkemudian dari candrasengkala jatuhnya Majapahit di Pararaton. Pujangga keraton telah mengubah informasi Pararaton (Nugroho, 2010: 168).

Peristiwa di atas ditambah kemudian dengan campur tangan media merupakan teks yang menarik untuk dicermati sebagai sebuah peristiwa yang utuh. Seni pertunjukan dianggap berperan penting untuk menyampaikan pesan teks tersebut. Seni pertunjukan diharapkan mampu menguatkan memori masyarakat terhadap teks tersebut dengan lebih kuat. Salah satu caranya adalah menghadirkan suatu bentuk teater lingkungan yang bu kan saja bentuk ini akrab dalam kehidupan masyarakat tradisional, juga akan dirasakan kontras oleh masyarakat modern.

\section{Intertekstualitas Cerita Sirna Ilang Kertaning Bumi}

Pemerintah kerajaan Majapahit yang terakhir adalah Kerta Bumi yang memerintah sampai tahun saka 1400 dengan sengkalan cunja-norayuganing-wong, atau tahun masehi 1478. Nama 'Kerta Bumi' digunakan sebagai candrasengkala dalam Serat Kanda untuk menyatakan lenyapnya kerajaan Majapahit akibat serangan tentara Demak yang terakhir; sirna-ilang-kertaning-bumi (tahun 1400). Dalam berita Tionghoa yang tersimpan di Klenteng Sam Po Kong di Semarang, dinyatakan pula bahwa Raja Majapahit yang penghabisan dan ditawan di Demak oleh tentara Demak ialah Kinta-bu-mi (Muljana, 2005:29). 
Sirna Ilang Kertaning Bumi yang menjadi judul pertunjukan teater kali ini berisikan tentang cerita runtuhnya sebuah kekuasaan karena ketidak pedulian penguasa terhadap nasib rakyatnya. Pergeseran politik Majapahit di tahun 1424 di mana hubungan kerjasama antara Majapahit dan negeri Tiongkok mulai dibuka secara resmi. Hubungan politik tersebut ternyata memberikan dampak luar biasa bagi kerajaan Majapahit. Kerajaan Majapahit mengalami pengeroposan baik dari dalam istana maupun dari luar. Salah satu cara pengeroposan itu adalah dengan menyusupkan mata-mata ke dalam istana termasuk menjalin hubungan pernikahan. Dari penelitian terbukti bahwa anak perempuan babah Ban Hong ini yang melahirkan Jin Bun atau Raden Patah. Raden Patah adalah putra Raja Majapahit Kong Ta Bu Mi, yakni Raja Kerta Bumi. Demikianlah putriputri Cina itu dijadikan umpan untuk memancing para pembesar Majapahit (Muljana, 2005:186).

Jika dikaji secara interteks, makna cerita dikaitkan dengan peristiwa sosial politik di Indonesia pasca runtuhnya rezim Orba, maka telah terjadi kemiripan pada beberapa peristiwanya. Misalnya saja kehadiran putri Cina dimaknai sebagai keberpihakan penguasa yang mengutamakan pengusaha Asing untuk mengembangkan usahanya di Negara Indonesia dengan berbagai kemudahan. Sementara pengusaha dalam negeri semakin tertinggal dan terkalahkan oleh pemodal asing. Hal tersebut mengakibatkan kesenjangan sosial antara masyarakat pribumi (pengusaha lokal) dengan pengusaha asing. Inilah yang diduga sebagai penyebab konflik horizontal di Indonesia.

Pernyataan ini seharusnya dapat diamati kembali pada struktur sosial yang sudah dibangun oleh pemerintah Belanda yang mengakibatkan awal konflik Pribumi-Muslim dengan Cina, sehingga melahirkan konflik-konflik berkepanjangan. Memang konflik antarstruktur sosial yang ada bukan murni karena keagamaan, namun berpadu dengan sosial-ekonomi. Pasca kemerdekaan konflik kelas bernuansa agama tersebut bukannya tuntas, tapi terus menjadi potensi dan bahkan menjadi aktual dalam bentuk kerusuhan SARA di Solo. Apalagi ketika masa Orde Baru, tingkat ekonomi PribumiMuslim terus berada di bawah bayang-bayang Cina yang kebanyakan Kristiani atau nonmuslim. Jarak sosial di antara kedua kelompok semakin menjauh, walaupun pemerintah mengusahakan proses pembauran melalui berbagai cara (Nawari, 2011:58).

Kemandulan putri Campa dalam cerita ini bisa saja dimaknai sebagai kurangnya kepercayaan negara pada generasi muda untuk memimpin negeri ini. Terlihat dari kandidat-kandidat calon presiden yang masih didominasi oleh tokoh-tokoh senior. Hal tersebut seakan tidak memberi ruang gerak bagi generasi muda untuk membuktikan kapasitasnya memimpin Negara. Hal tersebut bisa dimaknai seperti kegelisahan sang Raja yang belum memiliki keturunan untuk mewarisi tahtanya. Dengan demikian pertunjukan ini juga merupakan metafora dari realita sosial Negara Indonesia usai era Orde Baru.

Julia Kristeva menjelaskan bahwa kajian intertekstual adalah kerja sejumlah pengetahuan yang memungkinkan sejumlah teks-teks memiliki makna dan bahwa makna sebuah teks tergantung pada teks-teks lain yang telah menyerap dan mengubah bentuknya. Kristeva menyimpulkannya sebagai pengertian intersubjektivitas menjadi pengertian intertekstualitas (Culler, 1981:104). Kristeva melihat bahwa satu teks atau karya seni tidak dapat berdiri sendiri, artinya tidak otonom. Suatu karya seni tidak bisa lepas dari lingkungan dan pola berpikir penciptanya. Di mana ia berada serta bagaimana ia berpikir tentang suatu hal memberikan menginspirasi bagi karyanya. Karya seni tersebut berarti mempunyai keterkaitan dengan hal-hal lain di luar karya seni bahkan diluar penciptanya.

Julia Kristeva juga menjelaskan bahwa kajian intertekstual adalah kerja sejumlah pengetahuan yang memungkinkan sejumlah teks-teks memiliki makna: bahwa makna sebuah teks tergantung pada teks-teks lain yang telah menyerap dan mengubah bentuknya. Kristeva via Jonathan Culler (1981:104) menyimpulkannya sebagai pengertian intersubjektivitas menjadi pengertian intertekstualitas. Kristeva melihat bahwa satu teks atau karya seni tidak berdiri sendiri, tidak mempunyai landasan atau kriteria dalam dirinya sendiri-tidak otonom, Piliang (2003:121).

Teks telah melalui perkembangan yang semula berperan sebagai penanda suatu pesan saja maka kini telah berkembang dan memberi ruang yang lebih luas bagi pemberian makna oleh proses pembacaan. Minat strukturalisme untuk menarik simpul-simpul struktur dalam aktivitas berbahasa 
sebenarnya sudah menandakan kematian subjek. Dengan menelaah bahasa dalam kerangka sistem, tak ada lagi yang menaungi subjek selain relasi-relasi yang yang mempertautkan berbagai sistem penandaan. Penekanan Saussure bahwa bahasa adalah bentuk, dan bukan substansi, mempertegas bahwa kematian subjek diambang mata, dan filsafat sudah tidak bisa lagi menoleh pada antroposentrisme. Pencerahan untuk mempertahankan dirinya sebagai penguasa tunggal dalam medan pemaknaan yang kian lebar dan tak terbendung. Alternatif satu-satunya adalah dengan menenggelamkan diri dalam arus tanda yang bergerak dan membiarkan kematian subjek dalam rangka memberikan ruang bagi munculnya makna-makna baru (Al-Fayyadl, 2005: 61).

Maka pada kesempatan kali ini pemahaman secara intertekstual bertujuan untuk menggali secara maksimal makna-makna yang terkandung dalam sebuah teks. Apabila Roland Barthes, misalnya, menggali kualitas teks dengan cara menganggap karya seni sebagai anonimitas, yatim piatu, maka Kristeva justru dengan cara mengembalikannya ke dalam semestaan budaya, meskipun tetap sebagai kebudayaan yang anonim (Ratna, 2004:173).

Berdasarkan teori teks, setidaknya ada tiga teks besar yang mencoba dirangkum dalam pertunjukan teater Sirna Ilang Kertaning Bumi. Teks pertama adalah konflik horizontal pasca orde baru. Teks kedua adalah peristiwa keruntuhan kerajaan Majapahit. Teks ketiga adalah peranan pers menangkap fenomena sosial yang ada. Ketiga teks tersebut akan dirangkai dalam sebuah pertunjukan, sehingga mampu memberikan tafsir secara terbuka kepada siapa saja yang menangkapnya sesuai pengalaman masing-masing penonton. Peran teks sebagai penanda suatu makna menjadi pencipta makna-makna dengan lebih leluasa. Teks berkembang lebih lanjut dari yang semula berperan sebagai penanda suatu pesan saja, kini teks memberi ruang yang lebih luas bagi proses pembacaan dan pemberian maknamakna. Minat strukturalisme untuk membedah simpul-simpul struktur dalam aktivitas berbahasa sebenarnya sudah menandakan kematian subjek. Tidak ada lagi yang menaungi subjek selain relasi-relasi yang mempertautkan berbagai sistem penandaan. Medan pemaknaan semakin lebar dan tidak terbendung. Alternatif satu-satunya adalah dengan menenggelamkan diri dalam arus tanda yang bergerak dan membiarkan kematian subjek dalam rangka memberikan ruang bagi munculnya makna-makna baru (Al-Fayyadl (2005: 61)

Peran sutradara dan pertunjukan sebagai subjek telah dihilangkan dengan keikut sertaan penonton terlibat secara langsung di dalam proses pembacaan. Sutradara telah membebaskan penonton untuk memaknai pertunjukan, sehingga menangkap maksud dan memaknai pementasan ini bersifat subjektif. Penonton akan dibebaskan dalam memberikan makna atas pertunjukan tersebut sesuai dengan pengalaman masingmasing. Meski penulis telah menyampaikan teks tertentu, akan tetapi sangatlah tidak mungkin untuk menutup kemungkinan akan munculnya pemahaman yang berbeda antara penulis dengan penonton, bahkan antara penonton satu dengan penonton lainnya.

Kali ini peristiwa konflik horizontal yang terjadi di Indonesia saat era reformasi setelah tahun 1998 dimaknai sebagai pengulangan peristiwa yang terjadi pada saat keruntuhan Majapahit. Peristiwa konflik tersebut merupakan teks yang dicoba disandingkan dengan teks keruntuhan Majapahit menjadi sebuah teks baru (berupa sebuah karya seni) yang tidak mewakili budaya dari manapun atau anonim. Dalam perwujudan pertunjukan teater, dialog interteks yang akan terjadi adalah antara peristiwa konflik horizontal di Indonesia, peristiwa keruntuhan Majapahit, dan upacara adat Ceprotan yang telah mengalami adaptasi dengan kebudayaan modern. Upacara adat Ceprotan bisa menjadi inspirasi sebuah pertunjukan seni jika konteks dan fungsi upacara tersebut berubah.

Efficacy and entertainment are not so much opposed to each other; rather they form the poles of a continuum. The basic polarity is between efficacy and entertainment, not between ritual and theater. Whether one calls a specific performance "ritual" or "theater depends mostly on context and function". a performance is called a theater or ritual because of where it is performed, by whom, and under what circumstances. If the performance's purpose is to effect transformations - to be efficacious - then the other qualities listed under the heading "efficacy" will most probably also be present, and the performance is a ritual (Schechner,1977:120) 
Kegunaan dan hiburan tidak begitu banyak bertentangan satu sama lain, melainkan mereka membentuk kutub yang berkesinambungan. Hal yang berlawanan yang mendasar adalah antara kegunaan dan hiburan, bukan antara ritual dan teater. Apakah seseorang menyebutnya kegiatan "ritual" khususatau"teater sangat tergantung pada konteks dan fungsi". Kegiatan disebut teater atau ritual tergantung di mana itu dilakukan, oleh siapa, dan dalam situasi apa. Jika tujuan pertunjukan adalah untuk transformasi efek-untuk kegunaanmaka sifat-sifat lainnya yang terdapat dalam "kegunaan" akan sangat mungkin juga hadir, dan pertunjukan merupakan ritual.

\section{Sumber Ide Naskah Sirna Ilang Kertaning Bumi}

Sirna Ilang Kertaning Bumi merupakan candra sengkala atau penanda waktu. Candra sengkala itu sebenarnya bagian dari sengkalan, yaitu cara penulisan tahun yang disandikan dengan kalimat. Dengan kata lain adalah kalimat yang berarti angka tahun tertentu. Penulisan waktu/tahun dengan sengkalan ini banyak digunakan pada jaman Sastra Jawa Kuna dan Tengahan. Cara membacanya dibalik dari kanan ke kiri. Tanda/tahun saat hancurnya Majapahit disebutkan dengan Sirna Ilang Kertaning Bumi. Diterjemahkan dengan sirna $=0$, hilang $=0$, kerta $=4$, bumi $=1$. Dibaca dari kiri berarti tahun 1400 Saka atau tahun 1478 Masehi. Pada waktu itu perhitungan di Tanah Jawa menggunakan tahun saka. Kata Sengkala berasal dari kata saka dan kala. Saka dari bahasa Hindu sedangkan Kalaâ berarti waktu atau saat. Sakakala dimaksudkan pada saat ada seorang raja dari golongan Saka yang naik tahta di Hindia Selatan. Saat itulah dimulai perhitungan Tahun Saka, yaitu tahun 1 Saka yang bertepatan dengan tahun 78 Masehi.

Pemerintah kerajaan Majapahit yang terakhir adalah KertaBumi yang memerintah sampai tahun saka 1400 dengan sengkalan Cunja-norayuganing-wong, atau tahun masehi 1478. Nama KertaBumi digunakan sebagai candrasengkala dalam serat Kanda untuk menyatakan lenyapnya kerajaan Majapahit akibat serangan tentara Demak yang terakhir; sirna-ilang-kertaning-bumi (tahun 1400). Dalam berita Tionghoa yang tersimpan di Klenteng Sam Po Kong di Semarang, dinyatakan pula bahwa Raja Majapahit yang penghabisan dan ditawan di Demak oleh tentara Demak ialah Kinta-bu-mi (Muljana, 2005:29)

Sirna Ilang Kertaning Bumi adalah judul pertunjukan teater yang berisi cerita tentang runtuhnya sebuah kekuasaan karena ketidak pedulian penguasa terhadap nasib rakyatnya. Pada buku tulisan Slamet Muljana (2005:186) diuraikan secara singkat pergeseran politik Majapahit di tahun 1424 di mana hubungan kerjasama antara Majapahit dan negeri Tiongkok mulai dibuka secara resmi. Hubungan politik tersebut ternyata memberikan dampak luar biasa bagi kerajaan Majapahit. Kerajaan Majapahit mengalami pengeroposan baik dari dalam istana maupun dari luar. Salah satu cara pengeroposan itu adalah dengan menyusupkan mata-mata ke dalam istana termasuk menjalin hubungan pernikahan. Dari penelitian terbukti bahwa anak perempuan babah Ban Hong ini yang melahirkan Jin Bun atau Raden Patah. Raden Patah adalah putra raja Majapahit Kong $\mathrm{Ta} \mathrm{Bu} \mathrm{Mi}$, yakni Raja KertaBumi. Demikianlah putri-putri Cina itu dijadikan umpan untuk memancing para pembesar Majapahit. Sedangkan pendapat Slamet Muljana (2005:90) yang didapat dari serat kanda, kita lihat bahwa Prabu Brawijaya kawin dengan putri Cina sebagai tumbal kemandulan putri Campa. Putri Cina itu adalah anak saudagar Babah Bantong, teman Prabu Brawijaya. Kiranya nama Tionghoanya adalah Ban Hong. Demikianlah ibu Raden Patah adalah putri Cina anak saudagar babah Ban Hong.

Konteks kemandulan putri Campa masa kini bisa dimaknai sebagai kurangnya kepercayaan negara pada generasi muda untuk memimpin negeri ini. Terlihat dari kandidat-kandidat calon presiden yang masih didominasi oleh tokoh-tokoh senior. Hal tersebut seakan tidak memberi ruang gerak bagi generasi muda untuk membuktikan kapasitasnya memimpin negara. Maka hal tersebut bisa dimaknai seperti kegelisahan sang raja yang belum memiliki keturunan untuk mewarisi tahtanya. Dengan demikian pertunjukan Sirna Ilang Kertaning Bumi ini juga merupakan metafora dari realita sosial negara Indonesia usai era Orde Baru.

Jika secara interteks makna cerita dikaitkan dengan peristiwa sosial politik di Indonesia pasca runtuhnya rezim Orde Baru, maka telah terjadi 
kemiripan di beberapa peristiwanya. Misalnya saja kehadiran putri Cina dimaknai sebagai keberpihakan penguasa yang mengutamakan pengusaha asing untuk mengembangkan usahanya di Negara Indonesia dengan berbagai kemudahan. Sementara pengusaha dalam negeri semakin tertinggal dan terkalahkan oleh pemodal asing. Hal tersebut mengakibatkan kesenjangan sosial antara masyarakat pribumi dengan pengusaha asing. Hal tersebut diduga yang mengakibatkan konflik horizontal di Indonesia. Seperti pendapat Nawari Ismail (2011:58) berikut ini.

Persoalan ketimpangan sosial ekonomi nampaknya juga menjadi potensi konflik yang sewaktu waktu mencuat ke permukaan jika ada pemicu yang memungkinkannya. Informan muslim saya menuturkan :

Saya rasa persoalan sebelumnya bukan hanya pada hal keagamaan, tetapi perbedaan sosial kedua belah pihak, perbedaan tingkat ekonomi antara keduanya...

Pernyataan ini harus dilihat ke belakang mengenai struktur sosial yang sudah dibangun oleh pemerintah Belanda seperti dikemukakan di awal yaitu konflik pribumi-muslim dengan Cina, sehingga melahirkan konflik-konflik berkepanjangan. Memang konflik antarstruktur sosial yang ada bukan murni karena keagamaan, namun berpadu dengan sosial-ekonomi. Pasca kemerdekaan konflik kelas bernuansa agama tersebut bukannya tuntas, tapi terus menjadi potensi dan bahkan menjadi aktual dalam bentuk kerusuhan SARA di Solo. Apalagi ketika masa Orde Baru, tingkat ekonomi pribumi-muslim terus berada di bawah bayang-bayang Cina yang kebanyakan Kristiani atau nonmuslim, sehingga jarak sosial di antara kedua kelompok kian jauh, walaupun pemerintah mengusahakan proses pembauran melalui berbagai cara.

\section{Perwujudan Teater Sirna Ilang Kertaning Bumi}

Pada pertunjukan teater kali ini menggunakan tempat berupa rumah makan. Hal tersebut dipilih untuk mencapai efek kedekatan psikologis antara pertunjukan dengan penonton. Pada pertunjukan yang menggunakan bentuk panggung prosenium jarak estetis yang jauh akan tercipta di antara permainan dengan penonton. Dengan digunakannya rumah makan sebagai sarana per- tunjukan maka aksi-interaksi penonton dengan pemain secara langsung akan mudah terjadi. Untuk mencapai efek tersebut maka pada beberapa adegan akan melibatkan penonton untuk berdialog secara langsung dengan pemain.

Rumah makan merupakan tempat bertemunya berbagai individu baik yang berhubungan maupun yang tidak mempunyai hubungan antara satu sama lain baik secara personal maupun kelompok. Penggunaan tempat ini bertujuan untuk menciptakan suasana rileks dan keakraban. Peristiwa cerita yang dibangun tidak mengubah set dandekorasiaslikarenasengajaingin menghadirkan suasana asli tempat tersebut. Mengajak penonton berimajinasi sejenak meski tanpa terbawa hanyut hingga melibatkan empati. Peristiwa menyantap hidangan tetap akan dihadirkan sebagai peristiwa cerita. Meskipun suasana dan set tidak diubah akan tetapi penonton akan diajak untuk memberikan pemaknaan secara bebas terhadap peristiwa yang dihadirkan.

Theatrically, environment can be understood in two different ways. First, there is what one can do with and in a space. Secondly, there is the acceptance of a given space. In the first case one creates an environment by transforming a space; in the second case, one negotiates with an environment, engaging in a scenic dialog with a space. In the created environment the performance in some sense engineer the arrangement and behavior of the spectators; in a negotiated environment a more fluid situation lead sometimes to the performance being controlled by the spectator (Schechner, 1994:xxx).

Secara teatrikal, lingkungan dapat dipahami melalui dua cara berbeda. Pertama, seseorang bisa bekerja dengan lingkungan dan di dalam lingkungan. Kedua, menerima begitu saja lingkungan itu. Dalam kasus pertama seseorang menciptakan sebuah lingkungan dengan mengubah lingkungan yang ada; dalam kasus kedua, seseorang melakukan negosiasi dengan lingkungan, terlibat dalam dialog dengan lingkungan. Dalam lingkungan yang diciptakan seseorang melakukan penataan pada sikap penonton; dalam perundingan dengan lingkungan, situasi yang lebih bebas kadang-kadang menyebabkan pertunjukan dikendalikan oleh penonton. 
Usaha lain untuk menciptakan suasana "ringan" adalah dengan menggunakan nyanyian dan lagu-lagu sebagai pengganti dialog-dialog yang disampaikan. Beberapa adegan cerita mengalami tingkat kesulitan yang berbeda-beda antara satu dengan lainnya. Pada adegan yang sulit untuk menciptakan suasana tertentu akan dibantu menggunakan ilustrasi gerak sesuai dengan peristiwa yang dimaksud, sehingga penonton akan terbantu memahami suasana saat lagu tersebut dibawakan. Keberhasilan kerja kreatif seorang koreografer tergantung pada kemampuan daya khayalnya dalam mengejawantahkan pengalaman batin ke dalam gerak. Gerak itu bukanlah sebuah gerak yang sederhana, gerakan sehari-hari, tehnik, atau pantomime. Lebih dari semua itu, ia adalah gerak dalam bentuknya yang paling murni yang mengalir dari sumber yang paling dalam dan terulang secara imajinatif yang menghasilkan suatu ilusi-semacam pengalaman yang gaib. Pengejawantahan dari perasaan dan khayalan ke dalam gerakan, substansi kualitatif, adalah aspek yang paling esensial dalam proses kreatif

Pemain yang terlibat dalam proses perunjukan ini mempunyai latar belakang pengalaman seni yang berlain-lainan. Pada beberapa pemain yang mempunyai latar belakang penari tradisional tentu beberapa pola gerakan yang pernah ia latih akan berpengaruh dan muncul pada pembawaan tokoh yang dimainkannya. Sedangkan pada beberapa pemain yang kurang memiliki pengalaman dalam menari akan menggunakan latihan-latihan khusus dan mencoba mengeksplorasi gerakan sesuai dengan interpretasinya pada tokoh dan peristiwa yang akan disampaikan secara bebas. Gerakangerakan yang dieksplorasi tersebut mengacu pada lagu dan alunan musik dengan ritme maupun suasana tertentu.

Pemain berusaha menghayati dan mengikuti suasana lagu yang didengarkan. Sedikit demi sedikit para pemain mulai menyesuaikan gerakan tubuh dan anggota tubuhnya mengikuti suara yang ditangkap tersebut. Masing-masing pemain tentu akan menghasilkan gerakan yang berlainlainan sesuai dengan interpretasi masing-masing. Sambil terus bergerak, sutradara mengamati peristiwa eksplorasi tersebut dan memilih gerakan yang ditawarkan dari hasil eksplorasi tersebut.

Bahasa Jawa yang digunakan merupakan campuran antara Bahasa Jawa keseharian dan Bahasa
Jawa Kuna. Penggunaan Bahasa Jawa bukanlah tanpa alasan. Alasan digunakannya Bahasa Jawa adalah untuk memberikan ilustrasi bahwa kejadian cerita merupakan peristiwa keruntuhan kerajaan yang ada di Jawa dan bukan di tempat lain. Alasan lain digunakannya Bahasa Jawa Kuna adalah untuk memenuhi kepentingan efek pengucapan bunyi berupa sajak dan rima. Bahasa Jawa Kuna merupakan bahasa yang jarang atau bahkan tidak lagi dipakai dalam kehidupan sehari-hari untuk percakapan. Sehingga untuk memahami hal tersebut penonton cukup menyaksikan gerakan tubuh pemain, ekspresi serta mendengarkan suasana lagu yang dibawakannya.

Bila kita mengamati bagaimana seseorang pendengar menggunakan berbagai cara isyarat ekspresi dalam keseharian untuk merekognisi emosi, sangat dimungkinkan untuk menggunakan kombinasidarikinerjasuarayangtelahdisintesiskan. Seperti telah dikemukakan beberapa peneliti, memang sulit untuk mengetahui variasi kinerja mana yang penting sehubungan dengan ekspresi. Pertama-tama telah diketahui bahwa variasi tersebut adalah sistematis, sebagai lawan dari variasi acak atau noise (ribut) (Bengtsson, Gabrielsson, \& Thorsen, 1969). Reliabilitas kinerja dapat diukur misalnya dengan memberikan tugas pada penyaji untuk mengulangi interpretasi yang sama dari sebuah lagu beberapa kali. Selanjutnya, variasi variasi juga dapat menjadi bagian dari intensitas penyaji. Ini dapat diuji melalui manipulasi pada intensitas ekspresi. Akibatnya, dapat dipastikan bahwa semua variasi akan terasa oleh pendengar dan akan menjadi efektif bila berhubungan dengan ekspresi. Dengan kata lain, harus dapat diketahui variasi-variasi mana yang diperlukan oleh pendengar dalam mengatribusikannya. Hal ini dapat membuat pendengar bereksperimen dengan menggunakan variasi sistematis dalam mendengarkan berbagai variasi suara sebagai stimulus.

Beberapa permainan akan diwujudkan dengan adanya kor. Hal tersebut berfungsi untuk memberikan ilustrasi yang bersifat musikalitas, sehingga efek suasana tertentu bisa dihadirkan, misalnya suasana sakral pada pemujaan di sebuah tempat peribadatan. kor bukan hanya membantu dalam hal ilustrasi bunyi akan tetapi dalam pembawaannya juga akan divisualkan menggunakan komposisi-komposisi gerak. Komposisi 
gerak ini bertujuan untuk menciptakan harmonisasi gambar yang disesuaikan dengan lingkungan tempat pertunjukan berlangsung.

Usaha lain untuk menciptakan hubungan dengan penonton secara langsung terdapat pada tokoh-tokoh pembawa berita yang dihadirkan. Tokoh-tokoh tersebut merupakan representasi dari peran pers yang selama ini ikut terlibat dalam menciptakan komunikasi kehidupan bernegara di Indonesia. Seperti telah disampaikan di atas peran pers menjadi sangat penting dalam peristiwa konflik horizontal. Dalam kaitannya dengan penciptaan kali ini maka tokoh-tokoh pembawa berita akan melakukan peristiwa peliputan berita di lokasi peristiwa social yang digambarkan dalam pertunjukan. Sesekali peran pembawa berita tersebut akan melakukan wawancara secara langsung pada para penonton untuk meminta pendapatnya berkaitan dengan teks yang disampaikan, misalnya tentang konflik horizontal yang terjadi akhir-akhir ini.

\section{Penyutradaraan Teater Lingkungan Sirna Ilang Kertaning Bumi}

Menurut George R. Kernoddle (1967: 337339), ruang lingkup/wilayah kerja sutradara terdiri dari tiga tahap. Pertama, perencanaan. Kedua, pelatihan. Ketiga, pertunjukan. Tahap perencanaan adalah ketika ide naskah drama diterjemahkan menjadi naskah drama utuh. Setelah menyaksikan beberapa peristiwa kerusuhan yang ditayangkan melalui beberapa media, sutradara kemudian mencari gagasan atau ide cerita. Ide cerita yang mengambil rangkaian peristiwa keruntuhan Majapahit diperoleh setelah melakukan studi pustaka tentang kisah-kisah masa lampau baik itu legenda maupun sejarah. Setelah membaca beberapa kisah cerita, maka dipilihlah kisah keruntuhan Majapahit tersebut.

Setelah membaca kisah keruntuhan Majapahit penulis mulai melihat sebuah alur cerita yang menyerupai dengan peristiwa sosial di sekitar, yaitu berupa kerusuhan yang berakibat pada kerusakan. penulis beranggapan jika peristiwa kerusuhan tersebut terjadi terus menerus bukan mustahil akan terjadi kerusakan yang lebih besar pada stabilitas kehidupan Negara. Secara kebetulan tempat tinggal penulis berdekatan dengan tempat penyelenggaraan sebuah upacara adat bernama "ceprotan". Bentuk upacara adat yang menggunakan unsur tari-tarian serta tembang menjadikan inspirasi tersendiri dalam mengungkapkan bentuk penyajian. Dari mengamati serta bertanya secara langsung pada pelaku maka diperoleh beberapa ide untuk membuat sebuah pertunjukan teater ditempat terbuka.

Suasana keakraban yang tercipta antar warga dalam prosesi upacara tersebut menginspirasi penulis untuk membuat pertunjukan teater yang bernuansa keakraban pula. Interaksi antara pelaku upacara dengan warga setempat terjadi secara langsung pada beberapa bagian prosesi. Selanjutnya adalah mulai menyusun sinopsis cerita runtuhnya kerajaan Majapahit. Setelah itu ditulis tiap adegan dan dicari kemungkinan konflik-konflik permasalahannya. Penulis mulai membuat syair yang berkaitan dengan isi cerita. Tiap-tiap syair kemudian dibubuhkan nada-nada yang sesuai dengan suasana hati tokoh yang akan dimainkan sehingga menjadi sebuah lagu tema tiap adegan.

Perencanaan juga melingkupi visualisasi ruang, waktu, dan warna pemanggungan oleh sutradara. Bentuk pemanggungan yang akan dipakai telah ditetapkan sesuai dengan bagian prosesi upacara adat ceprotan yaitu luar ruangan. Bentuk teater lingkungan dinilai lebih tepat untuk mendapatkan nilai keakraban seperti upacara adat yang dimaksud. Setelah melalui survey maka dipilih sebuah ruang yang memiliki kaitan dengan cerita tersebut, yaitu sebuah Rumah Makan. Rumah Makan sebagai tempat orang menikmati hidangan juga sebagai tempat orang bertemu dan berdiskusi bahkan menyelenggarakan pesta perayaan tertentu dinilai tepat sebagi sarana menghadirka suasana keakraban. Pada beberapa adegan dalam cerita juga terdapat peristiwa perayaan serta adegan menyantap hidangan secara bersama-sama. Rumah makan yang digunakan dipilih yang bisa memberikan ruang agar dapat di sesuaikan mirip prosesi upacara adat yang menjadi inspirasi pertunjukan ini.

Tahap kedua adalah tahap pelatihan. Naskah diubah bentuknya menjadi tubuh dan suara aktor, serta perancang artistik merancang naskah menjadi elemen artistic pertunjukan. Untuk memperoleh pemain yang siap dengan konsep pertunjukan tersebut maka dibutuhkan beberapa tahap latihan tertentu. Pertama adalah konsentrasi. Pemain mulai mengheningkan pikiran. berkonsentrasi 
dengan bersikap rileks dan focus pada proses latihan. Mengatur pernafasan dan meditasi. Kedua adalah Membaca. Naskah berupa syair lagu dibagikan pada pemain dan sutradara untuk melakukan interpretasi bersama-sama. Latihan ini bertujuan untuk menyamakan persepsi tentang makna yang akan disampaikan sehingga pemain bisa mengekspresikan naskah sesuai dengan yang dimaksud. Ketiga adalah olah rasa. Dimulai dengan konsentrasi lalu menghayati cerita yang dibaca. Pemain membayangkan peristiwa yang akan dilalui tiap tokohnya sambil mendengarkan ilustrasi musik yang menyertainya. Latihan ini bertujuan untuk menumbuhkan kepekaan terhadap sensasi yang ditangkap saat mendengarkan nada-nada yang harus dibawakannya sehingga menghasilkan ekspresi yang sesuai dengan makna yang akan disampaikan dalam teks.

Olah suara dilakukan dengan sikap konsentrasi. Pemain berusaha mendengarkan bunyi dan nada dari alat musik. Secara perlahan-lahan pemain mulai menyuarakan nada-nada yang diproduksi oleh alat musik tertentu. Tahap selanjutnya adalah menyuarakannya dengan penuh keyakinan serta artikulasi yang jelas. Nada yang diikuti (ditirukan) divariasikan secara bertahap dari yang sederhana hingga tahap lebih rumit. Latihan ini bertujuan untuk melatih pengontrolan suara untuk memproduksi nada-nada yang diharapkan agar tidak terjadi sumbang atau salah interpretasi dalam penyuaraannya.

Olah tubuh juga dilakukan setelah hafal dan benar dalam menyuarakan lagu yang dibawakan, para pemain mulai berusaha menggerakkan anggota badannya. Latihan dimulai dengan mendengarkan iringan musik dan menggerakkan anggota badannya yang di sesuaikan dengan ritme yang ditangkap. Setelah mencari gerakan secara bebas menurut ritme tiap lagu yang akan dibawakannya, sutradara memilih beberapa gerakan yang ditawarkan dari proses tadi. Gerakan tersebut selanjutnya dihafalkan dan dihayati.

Setelah hafal dengan lagu dan gerakan, kini saatnya pemain melakukan keduanya secara simultan. Latihan belum diiringi oleh iringan musik. Pemain harus bisa mengungkapkan makna melalui ekspresi wajah serta gesture yang telah dipilih dengan penuh penghayatan. Latihan ini bermaksud melatih koordinasi antara pengungkapan melalui verbal dan gesture agar mendapatkan bentuk komunikasi yang bisa ditangkap oleh penonton meski bahasa verbal akan kurang ditangkap secara maksimal. Dengan pengekspresian lagu secara tepat diharapkan penonton mampu menangkap pesan yang akan disampaikan.

Untuk beberapa teks yang disampaikan secara verbal, pemain berusaha menghadirkan imajinasi tertentu utnuk melatih interaksi dengan penonton secara langsung. Setelah hafal dengan teks yang akan disampaikan maka para pemain mengucapkan sesuai dengan karakter masingmasing dengan menghadirkan imajinasi penonton yang akan diajak berbicara.

Blocking/penempatan posisi aktor adalah ketika pemain mencoba memainkan bagian peran masing-masing maka sutradara segera menentukan pola lantai serta garis permainan yang akan digunakan. Pemain kemudian mengaplikasikan permainannya pada garis yang telah dirancang tadi. Sementara itu sutradara tetap mengamati sambil mencari berbagai kemungkinan untuk
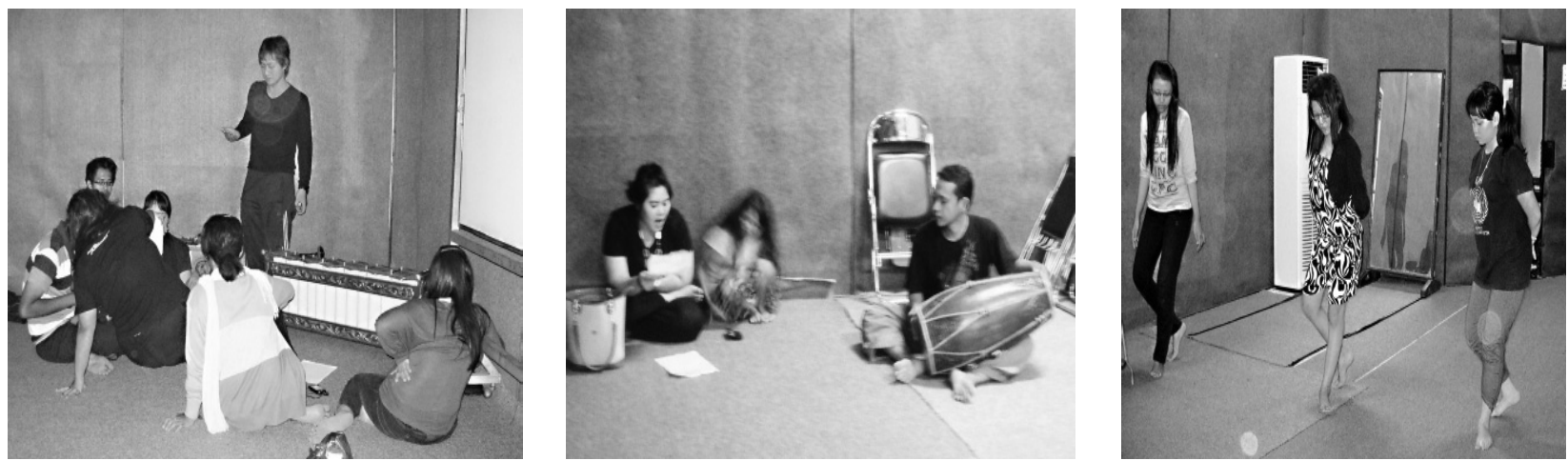

Gambar 1. Olah rasa, olah suara, dan olah tubuh ber basis tradisi Jawa dilatihkan kepada para pemain agar mereka mengenal dan merasakan budaya Jawa (Foto: Wahid) 
melakukan pengembangan agar permainan mempunyai dinamika yang diinginkan.

Tahap ketiga adalah tahap pertunjukan. Sebelum pertunjukan berlangsung penata artistik menawarkan gagasannya sesuai dengan konsep yang disampaikan oleh sutradara. Setelah disepakati bentuk rancangannya maka tugas penata artistik untuk mewujudkannya. Sutradara, penulis, dan desainer menyingkir. Stage manager dan crew panggung membantu aktor menghadirkan naskah di atas panggung. Penonton dipersilahkan untuk menempati tempat yang telah ditentukan.

Pilihan tempat Rumah Makan kiranya sesuai dengan konsep teater lingkungan Richard Schechner yang dikenal dengan " 6 aksioma-Schechner" (1994:xxx). Aksioma pertama adalah transaksi yang terjadi dalam sebuah pertunjukan teater. Terdapat tiga transaksi terjadi, yaitu antarpara pelaku, antar-anggota penonton, serta antara pemain dan penonton. Penonton yang terdiri dari kalangan sosial yang heterogen, diberikan keleluasaan untuk saling berinteraksi di antara mereka sementara alur pertunjukan terus berjalan. Keadaan tersebut merupakan satu bagian yang utuh dari pertunjukan ini.

Aksioma kedua yaitu dipergunakannya seluruh ruangan sebagai tempat pertunjukan. Di sana, ada dua keadaan yang perlu mendapat perhatian. Pertama, kadang pertunjukan melibatkan seluruh tamu Rumah makan. Ruang yang sengaja tidak diubah demi kepentingan pertunjukan serta membiarkan begitu saja pengunjung untuk menempati ruang seperti biasanya. Misalnya ruang pendopo dipergunakan untuk menyampaikan peristiwa cerita adegan pertama tanpa merubah set dekorasi maupun tata cahayanya. Seluruh pengunjung yang ada di tempat tersebut tidak dipisahkan dengan pemain bahkan dapat berinteraksi pada meja yang sama dalam satu ruangan.

Aksioma ketiga adalah secara teatrikal, lingkungan dapat dipahami melalui dua cara berbeda. Pertama, seseorang bisa bekerja dengan lingkungan dan di dalam lingkungan. Kedua, menerima begitu saja lingkungan itu. Meski dalam satu ruang yang sama pertunjukan tetap terdiri dari pemain dan penonton. Pada situasi tertentu pemain harus siap menghadapi reaksi penonton yang bersifat spontan. Reaksi spontan tersebut berpotensi memberikan tawaran-tawaran baru dan segar sebagai bagian dari pertunjukan. Sebagai misal, penonton yang diajak tokoh penari untuk menari bersama tidak dapat diprediksi secara tepat sebelumnya bagaimana reaksi yang akan muncul darinya kemudian. Pengunjung bisa saja menolak atau bereaksi secara berlebihan misalnya tidak mau berhenti untuk menari. Peristiwa lain misalnya reaksi penonton oleh pertanyaan-pertanyaan yang dilontarkan oleh tokoh wartawan sangat beragam dan tidak bisa diprediksi sebelumnya.

Aksioma keempat adalah kedudukan pertunjukan sebagai pusat perhatian tidaklah kaku dan semata-mata menuruti pemahaman sutradara. Para pemain hanya bertugas menyajikan permainan yang dinikmati dengan cara dan pemahaman yang berlain lainan oleh masing-masing penonton. Penonton bebas memilih unsur apa yang direspon atau dinikmatinya, seperti pada aksioma ke-empat yaitu titik perhatian yang fleksibel dan bervariasi.

Aksioma kelima adalah seluruh elemen produksi yang ada berbicara dalam bahasa mereka sendiri. Aksioma ini tersirat dalam yang lain. Ketika mendiskusikan aksioma pertama, penulis sekaligus sutradara menunjukkan bahwa kru harus menjadi bagian kreatif dari pertunjukan. Dalam teater lingkungan satu unsur pendukung tidak diabaikan demi yang lain. Bahkan sangat mungkin jika unsur ini akan dilatih secara terpisah, membuat pertunjukan itu sendiri sebagai tempat bermain atau bersaing dalam pertemuan saat awal pertunjukan. Baik semua atau bagian dari pertunjukan dapat diatur sehingga unsur produksi saling "bekerjasama." Semua bergabung untuk membuat satu kesatuan karya seni.

Pada pertunjukan ini terdapat kru-kru yang membantu terselenggaranya pertunjukan, sebagai misal kameramen dan fotografer. Kameramen dan fotografer hadir di tengah-tengah permainan sebagai bagian yang tak terpisahkan dari pertunjukan itu sendiri. Kru yang menata perlengkapan serta menyiapkan peralatan bagi jalannya prosesi permainan tidak ditutup-tutupi dan dibiarkan terlihat dan menjadi salah satu pemandangan dalam pertunjukan. Masingmasing pemandangan yang terlihat memberi makna yang beragam bagi penonton. Hal tersebut sangat memerlukan kesiapan bagi pemain untuk tetap melanjutkan permainannya sementara kru 


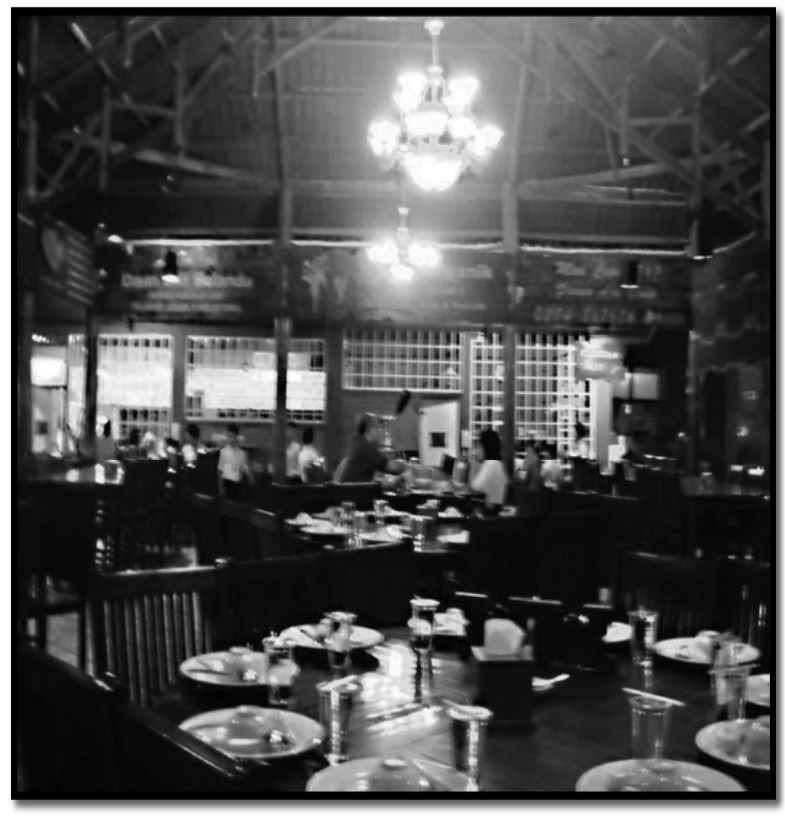

Gambar 2. Lokasi rumah makan tempat berlangsungnya pertunjukan teater Sirna Ilang Kertaning Bumi (Foto: Wahid)
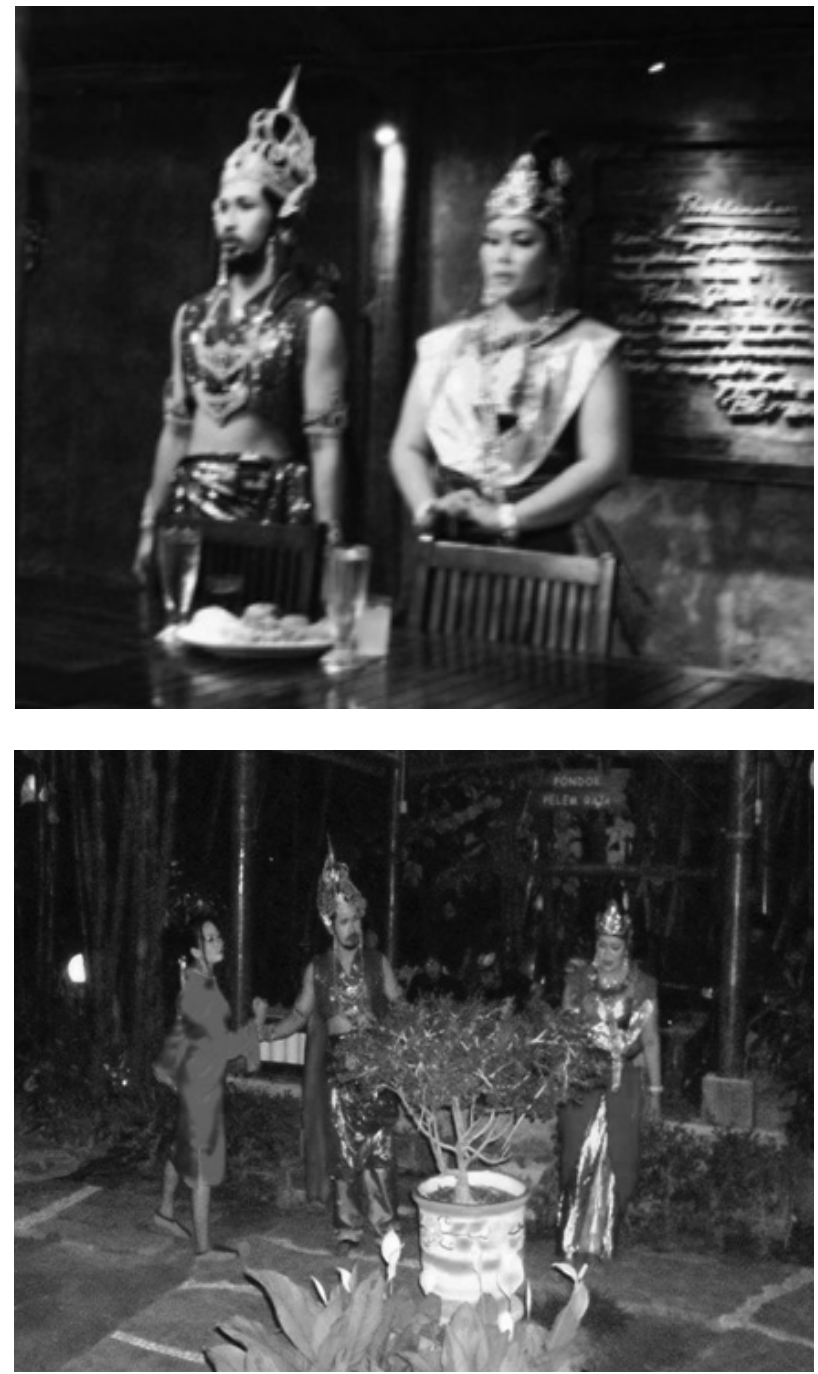

tetap bekerja di area permainan. Keduanya saling bekerjasama meskipun situasi dan kondisi sangat sulit untuk diprediksi.

Aksioma keenam, naskah tidak perlu menjadi titik awal atau tujuan dari sebuah produksi. Naskah bisa dihasilkan bersamaan atau bahkan setelah pertunjukan selesai. Pada pertunjukan teater lingkungan Sirna Ilang Kertaning Bumi naskah yang sudah diciptakan 'direvisi' kembali demi penyesuaian dan kepentingan pemanggungannya. Pada awal penciptaannya, naskah tidak dipersiapkan untuk ditampilkan dalam bentuk teater lingkungan. Akan tetapi ketika dirasakan ada manfaat tertentu dari pesan naskah untuk penonton, maka bentuk teater lingkungan menjadi bentuk yang tepat untuk menghadirkan naskah drama Sirna Ilang Kertaning Bumi.
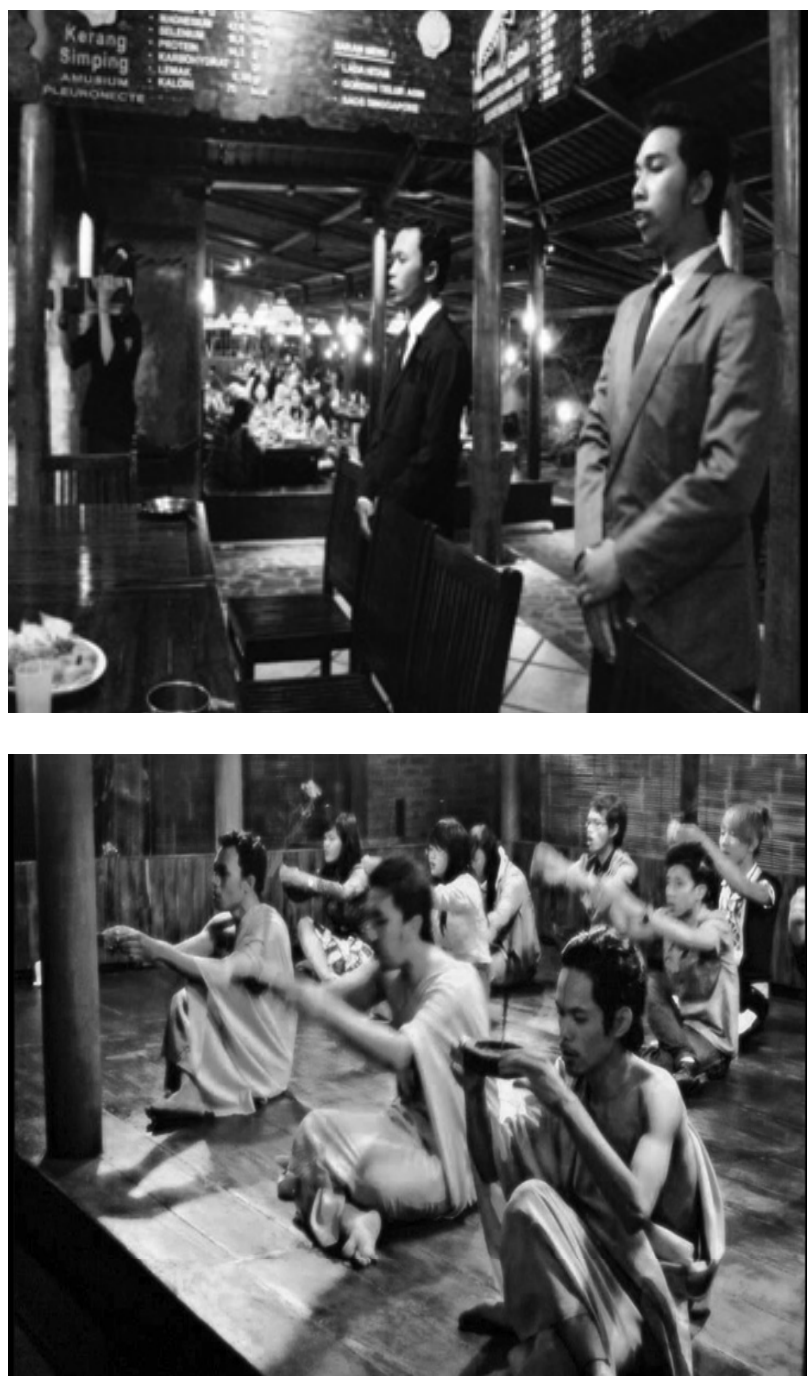

Gambar 3. Rumah Makan dan lingkungannya menjadi area permainan pertunjukan teater Sirna Ilang Kertaning Bumi (Foto: Wahid) 
Untuk teater lingkungan Sirna Ilang Kertaning Bumi permainan tidak menjadi hal yang utama, tidak ada keaslian, dan orang yang bekerja dalam produksi ini menjadi pelaku dan yang memberikan kesimpulan. Produksi Sirna Ilang Kertaning Bumi bisa saja diperuntukkan bagi seorang penciptanya, milik bersama, atau dibagi dengan penonton. Para pemain telah melalui tahap-tahap latihan secara terpisah dengan penonton maupun kru. Pemain dituntut untuk mampu mengembangkan permainan dari yang semula dilatihkan kemudian menjadi pertunjukan. Oleh karena sifat pertunjukan yang spontan maka latihan-latihan yang sebelumnya hanya merupakan pijakan awal untuk melakukan aksinya ketika bertemu dengan seluruh unsur pendukung pertunjukan yaitu penonton, kru serta ruangan yang dipergunakan saat berlangsung permainan. Naskah atau teks yang semula digunakan untuk latihan tidak mutlak untuk dijalankan, akan tetapi menyesuaikan dengan keadaan di saat pertunjukan berlangsung. Improvisasi saat interaksi dengan unsur-unsur pendukung pertunjukan mengeliminasi naskah yang telah dibuat sebelumnya dan membentuk teks baru yang dimaknai lagi oleh pemain, penonton maupun kru pendukung. Dengan demikian teks Sirna Ilang Kertaning Bumi memiliki kelonggaran dalam memaknainya.

Para pemain yang terlibat dalam proses pertunjukan Sirna Ilang Kertaning Bumi ini mempunyai latar belakang pengalaman seni yang berlainan. Pada beberapa pemain yang mempunyai latar belakang penari tradisional tentu dengan pola-pola gerakan yang pernah ia latih akan berpengaruh dan muncul pada karakter tokoh yang dimainkan. Pada beberapa pemain yang kurang memiliki pengalaman dalam menari telah menggunakan latihan-latihan khusus dan mencoba mengeksplorasi gerakan sesuai dengan interpretasinya pada tokoh dan peristiwa yang disampaikan secara bebas. Gerakan-gerakan yang dieksplorasi tersebut mengacu pada makna lagu dan alunan musik dengan ritme maupun suasana tertentu.

Pemain berusaha menghayati dan mengikuti suasana lagu yang didengarkan. Sedikit demi sedikit para pemain mulai menyesuaikan gerakan tubuh dan anggota tubuhnya mengikuti suara yang ditangkap tersebut. Masing-masing pemain tentu menghasilkan gerakan yang berlainan sesuai dengan interpretasi masing-masing. Sambil terus bergerak, sutradara mengamati peristiwa saat eksplorasi dan memilih gerakan yang ditawarkan dari hasil eksplorasi tersebut di permainan.

\section{Penutup}

Beberapa hal menarik yang harus diperhatikan dalam penciptaan pertunjukan teater lingkungan ini adalah kerjasama yang baik harus tercipta antara pencipta karya seni dengan pihak-pihak yang terkait dengan tempat dilaksanakannya pertunjukan. Pemilik Rumah Makan harus siap dengan beberapa tawaran dari kreator yang mempunyai resiko mengurangi kenyamanan pengunjung misalnya. Pengamatan secara detail dan menyeluruh terhadap kemungkinankemungkinan pada aksi dan reaksi pemain dan penonton mutlak dilakukan yang berguna untuk mempersiapkan pemain dalam berimprovisasi saat terjadi kontak langsung dengan pengunjung. Dibutuhkan keberanian dan kecerdasan bagi pemain untuk menanggapi reaksi pengunjung yang tidak bisa diprediksi.

Beberapahalyangperludicapaiantaralainadalah kontras antara pengunjung dengan pemain harus diciptakan secara tegas. Hal tersebut diperlukan untuk menarik perhatian penonton dengan kuat sehingga dengan rela ikut berpartisipasi dalam pertunjukan yang berlangsung. Nyanyian dan tarian haruslah mempunyai daya tarik yang kuat yang diperoleh dari penciptaan lagu dan geraknya maupun dari cara membawakannya. Kreatifitas yang tinggi bisa diperoleh dari kecerdasan dan pengalaman yang sudah diraih pada proses-proses berkesenian sebelumnya di tempat lain. Maka pada pementasan seperti ini dibutuhkan materi pemain dengan pengembaraan proses berkesenian yang lumayan matang.

Kesiapan kru dan pemain dalam menyambut penonton saat berinteraksi sangatlah dibutuhkan. Kesiapan mental dan keterampilan bermain akan menjadikan pementasan menjadi daya tarik bagi pengunjung untuk setia menikmatinya. Kesetiaan pemain dibutuhkan saat prosesi permainan berpindah tempat dari satu area ke area permainan berikutnya. Apabila daya tarik permainan tidak mampu menyerap perhatian penonton, maka penonton tidak akan tergerak untu mengikuti seluruh prosesi permainan. 
Bagi para seniman maupun kreator-kreator berikutnya diharapkan untuk berani menciptakan karya seni yang mampu menyuarakan pikiran sebagai refleksi lingkungan di mana si seniman tersebut hidup. Dengan keberanian tersebut karya seni tidak akan menjadi usang serta senantiasa segar dan memberikan manfaat sebesar-besarnya bagi masyarakat.

\section{Kepustakaan}

Al-Fayyadl. 2005. Derrida. Yogyakarta: LKis. Dean, Alexander. 1980. Fundamentals of Playing Directing. San Fransisco: Holt Rinehart And Winston.

Djohan. 2003. Psikologi Musik. Yogyakarta: Buku Baik Yogyakarta.

Fauzannafi dan Muhammad Zamzam. 2005. Reog Ponorogo Menari Di Antara Dominasi dan Keragaman. Yogyakarta: Kepel Press.

Goldberg, Roselee. 1988. Performance Art, From Futurism to the Present. London: World of Art.

Hadi, Y Soemandiyo. 2003. Aspek-Aspek Dasar KoReografi Kelompok. Yogyakarta: Elkaphi.

Ismail, Nawari. 2011. Konflik Umat Beragama dan Budaya Lokal. Jawa Barat: IKAPI.
Culler, Jonathan. 1981. The Pursuit of Signs, Semiotics, Literature, Deconstruction. London: Routledge \& Kegan Paul.

Hawkins, Alma M. 2003. Bergerak MenurutKata Hati, Metode Baru dalam Menciptakan Tari. Jakarta: Masyarakat Seni Pertunjukan Indonesia.

Kernodle, George R. 1967. Invitation To The Theatre. USA: Hartcourt

Muljana, Slamet. 2005. Runtubnya Kerajaan HinduJawa dan Timbulnya Negara-Negara Islam di Nusantara. Yogyakarta: Lkis.

Nugroho, Irawan Djoko. 2010. Meluruskan Sejarah Majapabit. Yogyakarta: Ragam Media.

Ratna, Nyoman Kutha. 2004. Teori, Metode, dan Teknik Penelitian Sastra. Yogyakarta: Pustaka Pelajar.

Schechner, Richard. 1973. Environmental Theater, An Expand Edition. New York: Applause. 1977. Performance Theory. New York: Routledge. 2002. Performance Studies. New York: Routledge.

Yudiaryani. 2002. Panggung Teater Dunia, Perkembangan dan Perubahan Konvensi. Jogjakarta: Pustaka Gondho Suli. 